\title{
Az országmárkázás lehetôségei nemzetközi szervezetekben az Európa Tanács magyar elnöksége kapcsán
}

\section{Eck Bence}

https://doi.org/10.47707/Kulugvi_Szemle.2021.2.04

Összefoglalás: A tanulmányban bemutatom! hogy az országmárkázás milyen eszközöket ad a kezünkbe, hogy pozitiv képet alakitsunk ki hazánkról egy nemzetközi szervezetben. Ezl követöen ismertetem. hogy ezek az eszközök miként érvényesülnek és érvényesithetök abban a 2021 májusában kezdödó féléves periódusban, amikor Magyarország látja el az Európa Tanács Miniszteri Bizottságának elnöki feladatait.

Kulcsszavak: országmárkázás. nemzetmárkázás. Európa Tanács, elnökség, nemzetközi szervezet

Abstract: In this study, I present the tools that country branding gives us to create a positive image of Hungary in an international organization. After that. I will show how these instruments are and could be enforced in the six-month period beginning in May 2021, when Hungary will chair the Committee of Ministers of the Council of Europe.

Keywords: country branding, nation branding, Council of Europe, presidency. international organization

A XX. század végétől a nemzetközi kapcsolatok szempontjából számos, napjaink nemzetközi viszonyait alapjaiban meghatározó folyamat bontakozott ki. A tanulmány fókuszát adó események is ebben az időszakban történtek, ugyanis 1990. november 6-án

\footnotetext{
1 A szerző Európa Tanács referens a Külgazdasági és Külüigyminisztériumban.
} 
Magyarország a keleti blokk országai közül elsőként csatlakozott az Európa Tanácshoz, illetve szintén az 1990-es években létrejött az országmárkázás mint önálló tudományterület ${ }^{2}$. A szakirodalomban az országmárkázás mellett, találkozni lehet a nemzetmárkázás (nation branding) és az állammárkázás (state branding) fogalmaival is, azonban ezek egymással egyenértékú elnevezések. ${ }^{3}$

Hogy megértsük az országmárkázás lényegét, fontosnak tar tom, hogy az összetett szó két eredőjét is értelmezzük. Egyrész rôl az ország alatt elsősorban azt az államot kell érteni, amely a nemzetközi jogban meghatározott feltételeknek ${ }^{4}$ megfelel és a nemzetközi közösség elismeri. Másrészről viszont e tudományágban nem feltétlenül szükséges az országmárkázási tevékenység vizsgálatához, hogy elismert államról legyen szó, mivel az állam elismeréséhez vezető úton számos más jellegű eszköz használata mellett az országmárkázás eszköztárának alkalmazása is elengedhetetlen. A fogalom másik alkotóeleme a márka, amely Patrick Barwise szerint alapvetően három csoportra osztható: lehet konkrét termék vagy szolgáltatás (pl.: Coca-Cola, Google), lehet márkajelzés (az adott márka logója, neve, jelmondata), illetve a fogyasztók termékről alkotott elképzelése (imázs). ${ }^{5}$ Mindezek alapján már kázás alatt e három csoport létrehozását együttesen kell érteni.

Ha az országmárkázás fogalmának lényegét szeretnénk megragadni, akkor azt mondhatjuk, hogy az országmárkázás voltaképp nem más, mint a márkázás technikai alkalmazása országokra, és ez által az ország reputációjának javítása, ami nagyobb

2 Eck Bence: Az országmárkázás átfogó vizsgálata a benne rejlö lehetóségek kiaknázá sa érdekében (2020). pp. 6. Utoljára letöltve: 2021.02.25. https://uni-nke.academia. edu/BenceEck.

3 Szondi György: Public Diplomacy and Nation Branding: Conceptual Similarities and Differences. Netherlands Institute of International Relations (2008).

4 Rendelkeznie kell területtel (legalább egy része szárazföldi), lakossággal és önálló kormányzattal.

5 Patrick Barwise: Brands and Branding: In: The Economist (2004). 


\section{Külïgyi Szemle}

versenyképességet, még inkább leegyszerűsítve „több pénzt” je lent. ${ }^{6} \mathrm{Az}$ országmárkázás továbbá rendelkezik azzal a tulajdon sággal, hogy minden ország esetében univerzálisan alkalmazható anélkuil, hogy az elmélet múködőképességét az adott ország mérete, fejlettsége vagy gazdasági ereje befolyásolná. Természetesen az imént felsorolt tényezőktől csak az elméleti múködés független, a márkázás hatékonyságára jelentős hatást gyakorol. ${ }^{7}$

\section{Az országmárkázás célkitűzése, célcsoportjai és eszközei}

Az országmárkázás legfőbb feladata, hogy pozitív képet alakítson ki a szóban forgó országról. Ennek létezik egy éppen ellentétes irányú válfaja, amelyet országképrombolásnak nevezünk, azonban e tanulmányban ezt a területet nem fejtem ki, hiszen az a tanulmány céljaival ellentétesen hatna. Tehát az ország reputációjának növelése jelenti a fó célkitűzést, amely azonban több módszerrel is elérhetô attól függően, hogy milyen célterületen kívánjuk javítani a már meglévő országképet. Az említett célterületek között a turizmus fejlesztését, a befektetések ösztönzését, az export ösztönzését és a nemzetközi szervezetekben betöltött meghatározott szerepet kell kiemelnünk. ${ }^{8}$

A célokat áttekintve el is érkeztünk a központi tématerülethez, mégpedig a nemzetközi szervezetekben alkalmazható országmárkázási tevékenységhez. A tanulmány fókuszában álló

6 Papp-Váry Árpád Ferenc: Országmárkázás [digitális kiadás], Akadémiai Kiadó (2020). Utoljára letöltve: 2021.02.25.

7 Eck Bence: Az országmárkázás átfogó vizsgálata a benne rejlö lehetöségek kiaknázása érdekében (2020). pp. 6. Utoljára letöltve: 2021.02.25. https://uni-nke.academia. edu/BenceEck.

8 Papp-Váry Árpád Ferenc: Az országmárkázás elmélete és gyakorlata. In: rekláMérték IV. évfolyam 34. szám (2006). 
kérdéskör különösen nagy figyelmet kap abban az időszakban, amikor hazánk látja el egy adott nemzetközi szervezet elnöki feladatait. Az Európa Tanács Miniszteri Bizottságának magyar elnöksége 2021 májusa és novembere között különleges lehetőségeket biztosít ahhoz, hogy a Magyarországról kialakított képet formáljuk. Összeségében elmondható, hogy az imázsépítésben kifejezetten fontos periódus az az időszak, amikor egy ország elnöki pozíciót tölt be, ugyanis ekkor jóval nagyobb figyelem övezi az ország nemzetközi szervezeten belüli tevékenységét. Általában az elnöklő ország komoly befolyást gyakorol az adott periódus szakmai tematikájára, továbbá nagyobb mozgástér áll rendelkezésére saját kultúrájának népszerū sítésére is.

Az országmárkázás tekintetében két fő célcsoportot külön böztethetünk meg: a külföldi és a belföldi lakosságot. A cél csoportokba történő kategorizálásnál érdekes eset a külhoni magyarok kérdése, hiszen ők bizonyos értelemben mindkét csoportba tartoznak, hiszen azok jellemzőivel egyidejűleg rendelkeznek. Mindez nem jelenti azt, hogy a külhoni magyarokat külföldinek tekintenénk, viszont az országmárkázás során őket speciális, köztes célcsoportként kell kezelni. Például feltételezhetô, hogy mindennapjaikban elsődlegesen nem a magyar sajtóorgánumokból tájékozódnak, ugyanakkor a magyar média iránt is élénk érdeklődést mutatnak, és ezáltal sokkal könnyebben jut el hozzájuk közvetlenül a kormány egy-egy lakosságot célzó üzenete. A két nagy célcsoport véleményének formálásához alapvetően eltérő stratégia és eszközrendszer szükséges, hiszen teljesen más szempontok és háttértudás alapján alakítják ki véleményüket a szóban forgó országról. A célcsoportok között megküilönböztethetünk további alcsoportokat, amelyek esetében eltérő eszközökkel alakítható ki pozitív kép. A külföldiek célcsoportja esetében ezeket a kommunikációs tényezőket és a fogadó fél által fontosabbnak ítélt tényezőket szemlélteti a Papp-Váry Árpád-féle országmárkázási kommunikációs „ablak”, mely szerint attól függően, hogy „ki áll” az 


\section{Külïgyi Szemle}

ablak másik oldalán, egyre inkább a makroökonómiai tényezők kerülnek a kommunikáció előterébe, az érzelmekre való ráhatás helyett. ${ }^{9}$

1. ábra

Az országmárkázás kommunikációs „ablaka”10

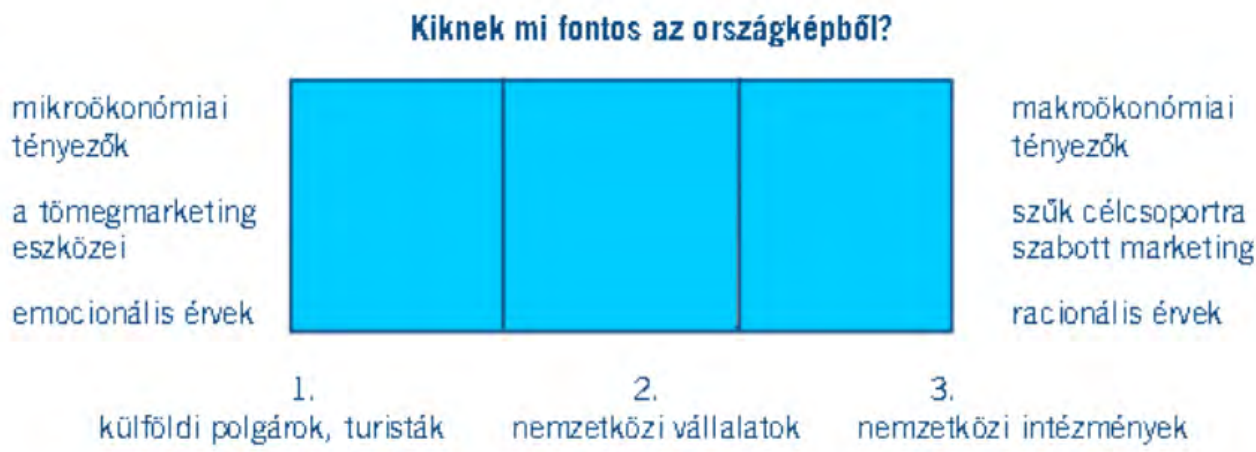

Az ablak három szárnyán a külföldi polgárokat, a nemzetközi vállalatokat és a nemzetközi szervezeteket láthatjuk, melyek közüil elóbbi kettővel egy későbbi tanulmányban fogok részleteibe menően foglalkozni. Az ablak egyik szárnyát tehát láthatóan az értekezésben elemzett nemzetközi intézmények alkotják, így ezáltal is megbizonyosodhatunk afelôl, hogy az országkép formálásának kiemelt jelentőségű színtere egy-egy nemzetközi szervezet. Véleményem szerint azonban kiemelendô az is, hogy egy ilyen speciális márkázási tevékenység esetén - mint amilyen a soros elnökségi periódus alatt megy végbe - sem szabad figyelmen kívül hagyni a belföldi célcsoportot. Egy ilyen időszak lehetőséget ad arra, hogy a nemzetközi szervezetben dolgozó magyar állampolgárokban kialakult országképre pozitív hatást gyakoroljunk, továbbá arra is, hogy a belföldi lakosság körében

9 Papp-Váry Árpád Ferenc: Az országmárkázás elmélete és gyakorlata. In: rekláMérték IV. évfolyam 34. szám (2006).

10 Papp-Váry Árpád Ferenc: Az országmárkázás elmélete és gyakorlata. In: rekláMérték IV. évfolyam 34. szám (2006). 
bemutassuk hazánk kontribúcióját a nemzetközi szervezet múködéséhez, és ezzel rávilágítsunk arra, hogy anyaországuk a szervezet vagy éppen a nemzetközi közösség elismert és megbecsült tagja, aki komolyan elkötelezett annak intézményes múködése mellett.

Az országmárkázás eszközrendszerét tekintve megküilönböztethe tünk rövid és hosszú távú márkázási apparátust annak függvényében, hogy milyen időintervallum az, amely alatt az adott tevekénység aktívan kifejti országkép formáló hatását. Rövid távú eszközök között azokat említhetjük, amelyek hatása azonnali és erős benyomást gyakorol a befogadóra, azonban kevés idő (fél-, egy év) elteltével minimálisra redukálódik a hatásuk. Az országimázs formálásának rövid távú eszközei elsősorban arra használhatók, hogy az erős impresszió segítségével felkeltsük a célcsoport érdeklődését országunk valamilyen szempont szerinti megismerése iránt. Általánosságban kijelenthetô, hogy az ebbe a csoportba sorolható eszközök közvetlen megtérülése gyors, azonban feltételes a tekintetben, hogy csak a befogadásra nyitott célközönségnél beszélhetünk bárminemú megtérülésről. Hosszú távú eszközök között viszont azokat említhetjük, amelyek hatása nagyon lassan - jellemzően 5-10 éves időtávban - érvényesül, illetve nem gyakorol egy hirtelen és erős benyomást a befogadóra, sőt éppen ellenkezőleg, a hosszú távú országmárkázási eszközöket az jellemzi, hogy lassan és fokozatosan fejti ki hatását, ezért a márkaépítés fontosabb eszközei ebbe a kategóriába sorolandók. Ezeknek az eszközöknek a megtérülése pénzügyi értelemben véve nehezen értelmezhető, hiszen hatásukat minimum 5 év elteltével kezdik éreztetni, viszont a rövid távúakhoz képest sokkal magasabb megtérülési rátát képesek produkálni. A hosszú és rövid távú eszközöket a továbbiakban számos példán keresztuil is illusztrálom.

Az országmárkázás eszköztárában alapvetően megkülönböztethe tünk tartalmi szempontból is csoportokat, amelyek a szakmai vagy kulturális lehatárolás mentén különülnek el. Fontos megjegyezni, hogy nem minden eszköz sorolható be tisztán az egyik csoportba, így ez az lehatárolás inkább egy skálaként értelmezhető, amelynek egyik végpontján a vegytiszta kulturális, míg a másikon a szigorúan szakmai ezközök helyezkednek el. 


\section{Külïgyi Szemle}

Az országmárkázás eszközrendszerét legjobban a „minden és sem mi” kijelentéssel lehet jellemezni, amely annyit tesz, hogy a legapróbb megjelenési felület és kapcsolódási pont is jelentőséggel bír a márkaépítés tekintetében, viszont a kormányok nem alkalmazhatnak olyan intézkedéseket, amelyek önmagukban csak az országimázs építésére koncentrálnak." Fontos továbbá kiemelni, hogy az országkép formálásának - mint általában a marketingtevékenységnek -, mindig az egyén a kulcsa, hiszen az ő percepciója és az általunk arra gyakorolt hatás adja meg a végső megtérüilés értékét, amely alapvető mutatószáma a hatékonyságnak.

\section{A magyar országmárkázás és lehetóségei az Európa Tanácsban}

Tanulmányom ezen részében bemutatom azokat a specifikus eszközöket, amelyeket Magyarország már alkalmaz az Európa Tanácsban, illetve felvázolok olyan lehetőségeket is, amelyek használatával tovább javítható a magyar országkép bármely nemzetközi szervezetben. A következő oldalakon a hosszú és rövid távú elválasztás mentén mutatom be az imázsformálási lehetőségeket, mivel meglátásom szerint e kategorizálás mentén egyértelmúbben meghatározható, melyik cso portba tartozik egy-egy vizsgált módszer.

Mielőtt azonban belefognék a rendelkezésre álló eszközrendszer áttekintésébe, elengedhetetlennek tartom megjegyezni, hogy Magyarország az Európa Tanácson belül rendelkezik egy olyan attribútummal, amellyel a szervezeten belül egyik ország sem. Mint azt a tanulmány elején is kifejtettem már, hazánk 1990. november 30-án csatlakozott az Európa Tanácshoz, amely dátum a nemzetközi szervezet életében is kulcsfontosságú. Magyarország csatlakozásával utat nyitott a keleti blokk többi országa előtt a csatlakozásra,

11 Eck Bence: Az országmárkázás átfogó vizsgálata a benne rejlö lehetöségek kiaknázása érdekében. (2020) pp. 15. Utoljára letöltve: 2021.02.25. https://uni-nke.academia. edu/BenceEck. 
ezzel jelentősen hozzájárulva a szervezet ténylegesen páneurópaivá válásához. Ez olyan alapot jelent, amely megkönnyíti az or szág nemzetközi szervezetben betöltött státuszának erősítését és az ország reputációjának növelését. Emellett Magyarország csatlakozása erôs üzenetet is közvetített a nemzetközi környezetben, hiszen jelezte az ország euroatlanti integráció iránti el köteleződését.

\section{Hosszú lávú eszközök}

A nemzetközi szervezetekben alkalmazható legkézenfekvőbb, az ország szervezeten belüli megbecsültségének javítására felhasználható eszköz a múködéshez való tartós, anyagi többlet-hozzájárulás. Ennek lényege, hogy a tagsággal járó kötelező terheken túlmenően egyéb forrásokat is a szervezet rendelkezésére bocsátunk. Az eszköz alkalmazásának alapvető politikai feltétele, hogy legyen egy olyan szakmai terület vagy intézmény a szervezeten belül, amelynek gyújtópontjában az ország számára is prioritásként kezelt témakör áll. A gyakorlati megvalósítás iskolapéldája, ha egy ország székhelyépüiletet ajánl fel a nemzetközi szervezetnek, amely segítségével állandó jelleggel becsatornázhatja magát területi alapon az intézmény vérkeringésébe. Az Európa Tanács vonatkozásában ennek az eszköznek az alkalmazása valósult meg 1995-ben, amikor a magyar felajánlás nyomán megalakult a Budapesti Európai Ifjúsági Központ (BEIK). Mindamellett, hogy a központ fenntartásának költségével Magyarország nettó befizetője az Európa Tanácsnak, megalapításával oly módon is kiemeli hazánkat, hogy a budapesti központon kívïl csak Strasbourgban ${ }^{12}$ található ifjúsági központ. ${ }^{13}$ A BEIK egy

12 Az Európa Tanács székhelyén található a Strasbourgi Európai Ifjúsági Központ.

13 EYCB25 https://www.coe.int/en/web/vouth/evcb25-intro. Utoljára letöltve: 2021.02 .25 . 


\section{Külïgyi Szemle}

olyan hozzájárulás magyar részről, amelyet az Európa Tanács vezetô tisztségviselői számontartanak és rendszeresen pozitív példaként említenek felszólalásaikban. Mindemellett a BEIK otthont ad számos képzésnek és rendezvénynek is, amelyek mind a civil lakosság, mind pedig a szakértők bevonásával valósulnak meg, ezzel is hozzájárulva a pozitív országkép erôsítéséhez.

Egy másik hosszú távú országmárkázási eszköz nemzet közi szervezetekben a hazai végrehajtás gyorsaságának biz tosítása. Ezzel a nemzetközi szervezetben folytatott munka tagállami elismertségét és eredményeinek fontosságát hang súlyozhatjuk, amely jelentősen képes növelni az ország re putációját az intézményen belül. Az Európa Tanácsban alkalmazható ilyen elem az Emberi Jogok Európai Bírósága (EJEB) előtt folyamatban lévő magyar ügyek végrehajtása. A végrehajtásra váró EJEB-ítéletek száma a 2016-ban rög zített negatív csúcsot jelentő 8962 ügyhöz ${ }^{14}$ képest mára jelentôsen redukálódott, 500 ügyre ${ }^{15}$. Ez a folyamat igen pozitív képet fest a magyar kormányzat elkötelezettségéról a Bíróság előtt felgyülemlett ïgyhalmaz csökkentésének tekintetében, azonban meg kell jegyezni, hogy a mintegy 95\%-os ügyszámcsökkenés ellenére hazánk még mindig a magasabb ügyszámmal rendelkezô országok csoportjába tartozik. Ez az országmárkázási eszköz kívánt hatékonysággal véleményem szerint akkor működne, ha az ügyszámot 100 alá lehetne szorítani. Ugyanakkor van egy, az előbbi problémánál égetőbb kérdés is, amely hátráltatja az eszköz érvényesülését, sőt rombolja a magyar országimázst. Folyamatosan növekszik ugyanis azon EJEB-ítéleteink mennyisége, amelyeket megerősített felügyeleti

14 European Court of Human Rights Analysis of Statistics 2016 (2017) Table 3 The Court's total caseload by stage of proceedings and judicial formation. Utoljára letöltve: 2021.02.25.

15 European Court of Human Rights Analysis of Statistics 2019 (2020) Table 3 - The Court's total caseload by stage of proceedings and judicial formation. Utoljára letöltve: 2021.02.25. 
eljárás alá vont a $\mathrm{CM} / \mathrm{DH}{ }^{16}{ }^{16}$ Ezen jelenség egyik negatív következménye, hogy a CM/DH üléseinek mindegyikén szerepel magyar ügy a napirenden. Ennek súlyos következménye Magyaror szág nemzetközi megítélésének romlása, melynek tovagyűrűző hatásai a nemzetközi szervezet keretein kívül is jelentős hatást gyakorolnak a magyar országképre. E folyamat negatív hatásainak csillapítására vagy akár megszüntetésére is jó lehetőséget kínál egy elnökségi időszak.

Az országmárkázás eszközrendszerének nemzetközi szervezetekben is alkalmazható egyik hosszú távú eleme kiemelten alkalmas arra, hogy hatásait a nemzetközi szervezet keretein kívül is hatékonyan érvényesítse. Ez az eszköz pedig nem más, mint az egy bizonyos szakmai területen betöltött vezető szerep elérése, amelynek kiépítése egy igen hosszú távú folyamat. Segítségével és a niche diplomáciai ${ }^{17}$ szemléletet alkalmazva az ország jelentősége a maximumra növelhető egy-egy kérdéskörben, amely az országmárka erôsítésére ideális hatást gyakorol a nemzetközi környezetben. ${ }^{18} \mathrm{E}$ hatás kiváltására a szakmai munka és a kérdéskörben való rendelkezésre állás mellett elengedhetetlen, hogy egy olyan kézzelfogható végtermék is létrejöjjön, amely megszilárdítja az ország jelentôségét az adott tématerület vonatkozásában. Magyarország az Európa Tanácsban két ilyen területen mutat aktivitást: a nemzeti kisebbségek védelme és a kibertér

16 Az Európa Tanács Miniszteri Bizottságának egy speciális formációja (Comité des Ministres/Droits de l'homme), amely az évi négyszeri ülésén az Emberi Jogok Európai Bírósága (EJEB) ítéleteinek végrehajtását vizsgálja politikai eljárás keretében.

17 Lényege, hogy egy kisebb ország kevesebb erőforrásokból gazdálkodhat, így kiválaszt néhány olyan területet, amelyekre kiemelt hangsúlyt fordít, és ezekkel alakítja az imázsát.

18 Eck Bence: A nyilvános diplomácia történeti és szerkezeti áttekintése, magyarorszá gi gyakorlatának vizsgálata (2018). Utoljára letöltve: 2021.02.25. https://uni-nke. academia.edu/BenceEck. 


\section{Külïgyi Szemle}

nemzetközi jogi szabályozása terén. ${ }^{19}$ Előbbi ugyan nemzetpoli tikai szempontból kiemelt jelentôségű, azonban fontos érzé kelni, hogy a nemzetközi környezetben kevés partner esetében jelenik meg kölcsönösen prioritásként, így országmárkázási szempontból nem mindig a leghatékonyabb erre támaszkodni. A nemzeti kisebbségek védelmével kapcsolatban azonban vitatha tatlan, hogy Magyarország következetes és határozott állásfog lalásának köszönhetően már megkerülhetetlen szereplője e kér déskörnek. A másik, országmárkázási szempontból önmagában nagyobb lehetőségeket hordozó terület a kibertér nemzetközi jogi szabályozása. E területhez minden országnak komoly érdekeltségei füződnek, illetve a digitalizáció jelentőségének folyamatos erősödése katalizátorként jelentkezik a nemzetközi jogi szabályozás fejlesztésének és kialakításának tekintetében. Látni kell, hogy e területen rengeteg érdeket kell egyeztetni, illetve a témában való munkájának köszönhetően véleményvezérként történő elismertségért is több ország van versenyben. Magyarországnak e területen sikerült egy komparatív előnyre is szert tennie, ugyanis a kiberbűnözés elleni küzdelem legátfogóbb és eddig egyetlen nemzetközi jogi egyezményét Budapesten írták alá. A multilaterális nemzetközi egyezményekre bevett szokás az aláírás helye szerinti város nevével hivatkozni, így a Számítástechnikai Bűnözésrôl szóló Egyezményre ${ }^{20}$ például, Bu dapesti Egyezményként. Ennek praktikus okai mellett országimázs szempontból is különös jelentősége van, hiszen általában a témában különösen érdekelt országban köttetnek, továbbá a későbbiekben még a laikus szemlélőkre is érvényesíti márkázási funkcióit. Ebből kifolyólag az ország reputációjának javításához elemi szükséglet, hogy nemzeti érdekeink érvényesítése közben

19 Budapest Convention and related standards. Council of Europe. https:// www.coe.int/en/web/cvbercrime/the-budapest-convention. Utoljára letöltve: 2021.02 .25 .

20 2001. november 23-án Budapesten írták alá. Magyarország a 2004. évi LXXIX. törvényben hirdette ki. 
kiemelt figyelmet fordítsunk - amennyiben lehetőség kínálkozik rá - egy-egy jelentősebb nemzetközi szerződés hazai miliőben történő aláírásának biztosítására.

\section{Rövid távú eszközök}

A rövid távú eszközök leggyakrabban használt válfaja a programszervezés, amelynek segítségével erős pillanatnyi figyelmet irá nyíthatunk egy témára. Ezek a nemzetközi szervezetek tekinteté ben elsődlegesen a kulturális programok, melyeken nagy számban vesznek részt a diplomácia testület tagjai és a nemzetközi szer vezetben dolgozó szakértők, illetve bizonyos alkalmakkor a civil lakosság és a sajtó is. E programok jó lehetôséget biztosítanak az ország promóciójára, viszont országmárkázási szempontból tekintve megtérülésük kérdéses. Egy elnökségi periódus alatt mindamellett, hogy a kulturális programok száma exponenciálisan megnő, nagyobb lehetőség nyílik szakértői események megszervezésére is. A szakmai programok segítségével szondázható, hogy a nemzetközi szervezetben milyen mértékben mutatkozik nyitottság egy új tématerület bevezetésére vagy a témában tör ténő munkafolyamatok elmélyítésére. Ezekkel a programokkal megfelelően előkészíthető az országmárkázás hosszú távú esz közeinek bevezetése. Minden program könnyedén hosszú távú eszközzé alakítható akkor, ha azokat sikerességük után bizonyos időközönként minimális módosítások megtételével megismételjük, ezzel tematizálva az éves programciklus egy részét, és így frissen tartva az általuk kiváltott pozitív imázsépítő hatást. Az Európa Tanács vonatkozásában magyar részről évente visszatérő kulturális program a Snétberger Zenei Tehetség Központ tanítványainak koncertje.

Az ajándékok átadása is egyfajta imázsépítő eszköz, azonban fontos kiemelni, hogy ezek hatása jelentősen korlátozott, és hatékonyságát számos tényező hátráltatja. Azonban egy-egy kreatív, 


\section{Külïgyi Szemle}

praktikus és márkázási üzenetet is hordozó ajándéktárgy jól alkalmazható országmárkázási eszközként is. Az ajándékok közüil leghatékonyabb, amikor egy nagyértékü tárgy átadására kerül sor magas szinten. Ennek imázsépítỏ hatása azért érvényesüil magasabb hatásfokkal, mert az átadásról gyakran jelenik meg hír a sajtóban és közösségi médiában, illetve ezeket az ajándéktárgyakat általában kiállítják a nemzetközi szervezetek köz pontjában. ${ }^{21}$

Az országmárkázás egyre növekvő jelentőségű és elterjedtségű rövid távú eszköze a közösségimédia-felületek és honlapok működtetése. Ezek a platformok alacsony költségráfordítás mellett képesek elérni rendkívül széles rétegeket, azonban csak megfeleló stratégia alkalmazása esetén. Tudni kell, hogy melyik felületen milyen formában lehet a legeredményesebben célba juttatni az üzenetet, amelynek alapja az oldalakat múködtető algoritmusok ismerete. Mivel a digitális térben óriási információbőség tapasztalható, elsősorban rövid távú eszköznek kell tekinte nünk az imént említett felületek alkalmazását, mivel a felhasz nálók minimális idő alatt döntenek arról, hogy érdekli-e őket az általunk generált tartalom. Viszont tisztában kell lenni azzal a ténnyel is, hogy ami egyszer az internetre került, azt szinte lehetetlen eltüntetni onnan, így ritka esetekben hosszútávon is kifejti hatását. Ezen felületek közül nemzetközi szervezetek esetében a többnyelvű dedikált honlap mellett elsősorban a Twitter használata terjed el elsődleges kommunikációs csatornaként. ${ }^{22}$ Amint azt már korábban említettem, egy soros elnökséget adó ország tevékenységét mindig nagyobb figyelem övezi, mint az egy átlagos tagállam esetében megszokott, amely természetesen a digitális térben

21 Magyarország ajándékai és az adományozás éve az Európa Tanácsnak: A Diploma Andreanum másolata (2004), eredeti 1956-os forradalmi zászló (1999), az Aranybulla másolata (1992), Medgyessy Ferenc: Táncoló lány (1990) https:/ www.coe.int en/web/portal/hungary. Utoljára letöltve: 2021.02.25.

22 Radhika Chhabra: Twitter Diplomacy: A Brief Analysis (2020). Observer Research Foundation. Utoljára letöltve: 2021.02.25. 
történő megjelenések tekintetében is érvényes. Ezért kiemelt jelentőségű, hogy a digitális felületeket megfelelően készítésék elő egy elnökségi periódusra. A digitális tér jelentőségét egyre többen felismerik - így a nemzetközi szervezetk is -, az Európa Tanács részérôl példának okáért határozott elvárás, hogy az elnökséget adó ország múködtessen kifejezetten elnökségi honlapot és legyen aktív a közösségi médiában is.

Végezetül meg kell említenem egy, kimondottan a nemzetközi szervezetekben való elnökségekhez kapcsolódó, rövid távú eszközt, amely nem más, mint az elnökségi prioritások megfogalmazása. Meglátásom szerint alapos átgondolást igényel mind politikai, mind pedig szakmai szempontok szerint, hogy miket jelöljön meg egy adott ország elnökségi prioritásainak. Ezzel ugyanis nem csak a számára fontos irányba tudja terelni a bizottságokban folyó munkát, de ideológiáját is képes népszerúsíteni általuk. Az országmárka alapját pedig nem más adja, mint az ország működéséről, berendezkedéséről és az állampolgárairól kialakított, gyakran elóítéletekkel teli kép. A nemzetközi szervezetek szintjén tehát az elnökségi prioritások ugyan időszakosan, de jó lehetôséget biztosítanak a magyar országimázs gondozására és finom alakítására.

\section{Összegzés}

A globalizációs folyamatok hatására megemelkedett a nemzet közi szervezetek jelentősége, különösen a tekintetben, hogy függetlenségüik által különböző nyilatkozataikat és értékítéleteiket a legtöbben objektívnek tekintik. Ennek köszönhetően az országmárkázás egyik kulcsterületének számítanak, amelynek gondozására különös figyelmet kell fordítani. Mivel a jó reputáció és ezáltal egy erős országmárka kialakítása minden országnak politikai, illetve gazdasági érdeke, elengedhetetlen az elérhető imázsépítő eszközök alkalmazása. 


\section{Külïgyi Szemle}

Ki kell emelnem azt is, hogy csak akkor múködtethetô megfele lően és hatékonyan az országmárkázás, ha a rövid és hosszú távú eszközöket párhuzamosan alkalmazzák. A kívánt eredmények elérése érdekében egyenlő arányban kell alkalmazni a két eszköztípust, hiszen hiába kell az országimázs fejlesztésére mint egy hosszú távú folyamatra tekintenünk, a pillanatnyi benyomások is fontos hatást gyakorolnak az országkép alakulására. Ezek az elvek nemzetközi szervezetekben különösen érvényesülnek, hiszen a szervezetben dolgozó apparátus lassan és alig cserélődik, viszont a diplomáciai testületet egy állandó periodikus változás jellemzi.

A tanulmányom végéhez érve fontosnak tartom ismételten hangsúlyozni, hogy bármilyen megjelenési felüilet és kapcsolódási pont nagy hatást gyakorol az országmárkázás eredményességére, viszont a kormányok nem alkalmazhatnak olyan intézkedéseket, amelyek önmagukban csak az országimázs építésére koncentrálnak. Ennek a bonyolult feltételnek a feloldására, úgy vélem, minden országban fontos lenne létrehozni egy olyan kormányzati intézményt, amely országmárkázási stratégiát alkot meg, és a minisztériumoktól függetlenül képes kiemelni azokat a tényezőket, amelyek mentén az ország reputációja továbbfejleszthető. Ez a szervezet egyesíthetné a kormányzati kommunikációban és a magánszektorban használatos márkázási módszereket, elérve ezzel a leghatékonyabb országmárkázási mûködést a hazai és nemzetközi környezetben egyaránt.

\section{Bibliográfia}

\section{Felhasznált irodalom}

„Ahány turista, annyi vélemény” (2000) In: Metro újság, 2000. április 7. Eurpoean Court of Human Rights Analysis of Statistics 2016 (2017) Table 3 - The Court's total caseload by stage of proceedings and judicial formation. Utoljára letöltve: 2021.02.25. 
Eurpoean Court of Human Rights Analysis of Statistics 2019 (2020) Table 3 - The Court's total caseload by stage of proceedings and judicial formation. Utoljára le töltve: 2021.02.25.

Fiona Gilmore: A country - Can it be repositioned? Spain - the success story of count ry branding. In: Journal of Brand Management (2002).

Jozef Bátora: Public Diplomacy in Small and Medium-Sized States. Netherlands Institute of International Relations (2005).

Keith Dinnie: Nation Branding: Concepts, Issues, Practice. Butterworth Heinemann (2007).

Kiberfenyegetések és kibervédelem. In: Infojegyzet 2016/44. (2016). Utoljára letölt ve: 2020.02 .25 .

Kiss Balázs: Missziótól marketingig. Médiakutató Alapítvány (2006). Utoljára letölt ve: 2021.02 .25 .

Nagy Lilla: EU-elnökség és magyar országkép. Külügyi Szemle, 2010/4. (2010)

Nancy Snow és Philip M. Taylor: Routledge Handbook of Public Diplomacy. Routledge (2008).

Papp-Váry Árpád Ferenc: Az országmárkázás elmélete és gyakorlata. In: rekláMérték IV. évfolyam 34. szám (2006).

Papp-Váry Árpád Ferenc: Country branding as a special type of place branding - An overview of the related terminology. In: Szikora, Péter; Fehér-Polgár, Pál (szerk.) 17th International Conference on Management, Enterprise, Benchmarking (2019).

Papp-Váry Árpád Ferenc: Országmárkázás [digitális kiadás]. Akadémiai Kiadó (2020). Utoljára letöltve: 2021.02.25.

Papp-Váry Árpád Ferenc: Országmárkázástól a versenyképes identitásig - A country branding megjelenése, céljai és természete (2009). In: Marketing és Menedzs ment 2009. évi 2. szám.

Papp-Váry Árpád Ferenc; Farkas Máté: Who has the strongest brand? The position of the Visegrád Four in country brand rankings. In: Szikora, Péter; Fehér-Polgár, Pál (szerk.) 17th International Conference on Management, Enterprise, Bench marking (2019). 


\section{Külïgyi Szemle}

Patrick Barwise: Brands and Branding. In: The Economist (2004).

Phillip Everts: Introduction. In: Public Opinion and the International Use of Force (2001).

Public diplomacy stratégiák. Századvég Politikai Iskola Alapítvány, Buda pest.

Radhika Chhabra: Tivitter Diplomacy: A Brief Analysis (2020). Observer Research Foundation. Utoljára letöltve: 2021.02.25.

Simon Anholt: Compelitive Identity - The New Brand Management for Nations, Cities and Regions. Palgrave Macmillan (2007).

Szondi György: Public Diplomacy and Nation Branding: Conceplual Similarities and Differences. Netherlands Institute of International Relations (2008).

Szondi György: The Role and Challenges of Country Branding in Transition Countries: The Central and Eastern Europe experience. Place Branding and Public Diplomacy (2007).

Wally Olins: A má̊kák - A márkák világa, a világ márkái. Jószöveg Mủhely Kiadó, Budapest (2004).

\section{Internetes.források}

Budapest Convention and related standards. Council of Europe https:// www.coe.int/en/web/cybercrime/the-budapest-convention. Utoljára letöltve: 2021.02.25.

Eck Bence: A nyilvános diplomácia lörléneti és szerkezeli állekintése, magyarországi gyakorlatának vizsgálata (2018). Utoljára letöltve: 2021.02.25. https://uni-nke.academia.edu/BenceEck.

Eck Bence: Az országmárkázás álfogó vizsgálata a benne rejlö lehetóségek kiaknázása érdekében (2020). Utoljára letöltve: 2021.02.25. https:// uni-nke.academia.edu/BenceEck. 
EYCB25 https://www.coe.int/en/web/vouth/eveb25-intro. Utoljára le töltve: 2021.02.25.

Magyarország ajándékai és az adományozás éve az Európa Tanácsnak. A Dip loma Andreanum másolata (2004), eredeti 1956-os forradalmi zászló (1999), az Aranybulla másolata (1992), Medgyessy Ferenc: Táncoló lány (1990). https://www.coe.int/en/web/portal/hungary. Utoljára letöltve: 2021.02 .25 .

Twiplomacy Blog (twiplomacy.com). Utoljára letöltve: 2021.02.25. 